Bangl. J. Vet. Med. (2007). 5 (1 \& 2): 87-91

\title{
PATHOLOGY OF TRACHEA AND LUNGS OF BUFFALOES
}

\author{
M. Akbor, M. G. Haider, F. Ahmedullah, M. A. H. N. A. Khan, M. I. Hossain and M. M. Hossain \\ Department of Pathology, Faculty of Veterinary Science, Bangladesh Agricultural University, \\ Mymensingh-2202, Bangladesh \\ *Corresponding author's e-mail address: mmhossain04@yahoo.com.au
}

\begin{abstract}
Pathological conditions of trachea and lungs of slaughtered buffaloes were investigated in the present study. A total of 80 slaughtered buffaloes were examined individually and trachea (80) and lungs (80) were collected for histopathology from the slaughterhouses of Barisal sadar, Barisal, Bangladesh, during the period from July 2006 to March 2007. Among them 9 trachea and 30 lungs were found to be apparently abnormal in naked eye. Grossly, tracheal and lungs lesions were $11.25 \%$ and $37.5 \%$ in buffaloes, respectively. The gross tracheal lesions were petechial haemorrhages on the mucosa of trachea and lungs lesions were haemorrhage and congestion in lungs (16.25\%), hard nodule formation (7.5\%), cyst in lungs (6.25\%), emphysematous lung (5\%) and thickened pleura (2.5\%). In histopathology, congestion (5\%) and mild tracheitis (8.75\%) were recorded as tracheal lesions. Histopathological examination of lungs noticed a number of conditions or lesions such as chronic interstitial pneumonia (3.75\%), edema fluid (3.75\%), broncho-pneumonia (3.75\%), bronchitis (2.5\%), bronchiolitis (2.5\%), pneumonia-congested stage (8.75\%), hydatid cyst (6.25\%), fibrinous pneumonia (3.75\%), healed nodule (7.5\%), purulent broncho-pneumonia (1.25\%), fibrino-purulent pneumonia (1.25\%), subacute fibrinous pneumonia (1.25\%), pulmonary adenomatosis (1.25\%), pleuritis (2.5\%) and hemosiderosis (3.75\%). For morphological descriptions, the lesions were categorized into various types; however a single section showed intermixed of various lesions.
\end{abstract}

Keywords: Pathology, trachea, lungs, buffaloes

\section{INTRODUCTION}

In recent years, the buffalo commonly known as an "Asian Animal” has attracted global concern. The buffalo is the dairy, draught and meat animal of Asia. The Indian subcontinent is the home tract of the world's dairy buffaloes. Today in India, the water buffalo is recognized as her milk machine. It accounts for more than half of India's total milk production, although it constitutes only one third of the total milch population (Banerjee, 1998). The domesticated buffaloes are mainly found in the coastal areas of Asia mainly India, Malaysia, Singapore, Philippines, Thailand, Indonesia, Southern-China and other countries of the Far East. Total world buffalo populations are 138.37 million among which in India (75 million), China (20 million), Pakistan (13 million), Thailand (6 million) (Banerjee, 1998) and Bangladesh (8 million) (BBS, 2003). The diseases of the respiratory system, either acute or chronic, cause debility and death leading to great economic loss. This loss can be minimized by prevention and treatment of the diseases, affecting the respiratory system, after proper diagnosis. In Bangladesh, few works have been performed on some aspects of buffalo diseases (Dewan et al., 1979; Hossain and Baki, 1987; Hossain, 1990; Hossain et al., 1991) but no systemic works have been performed on buffalo respiratory system. Therefore, the present investigation was undertaken to study the pathological lesions of trachea and lungs of buffaloes after slaughter.

\section{MATERIALS AND METHODS}

\section{Collection of samples}

A total of 160 (trachea $=80$, lungs $=80$ ) samples were collected from buffaloes after slaughter from two slaughterhouses of Barisal sadar, Barisal, Bangladesh, during the period from July 2006 to March 2007. After slaughter, gross tissue changes were observed and recorded carefully by observation in naked eye. Besides, samples were collected in $10 \%$ buffered neutral formalin for histopathology. All the samples were transferred to Histopathology Laboratory and Bacteriology Laboratory of the Department of Pathology, Bangladesh Agricultural University, Mymensingh for histopathology. 


\section{Histopathology}

The tissue samples were trimmed properly and fixed for $24 \mathrm{~h}$ more. To remove the fixative, the tissues were kept in running tap water for overnight. The tissues were dehydrated in ascending grades of alcohol. The tissues were cleared by two changes in chloroform. The tissues were embedded with molten paraffin wax. Paraffin blocks containing tissue pieces were made using templates. The tissues were sectioned with a rotary microtome at $5 \mu \mathrm{m}$ thickness. Then the sections were allowed to spread on warm water bath $\left(45^{\circ} \mathrm{C}\right)$ and taken on oil- and grease- free glass slide. A small amount of gelatin was added to the water bath for better adhesion of the sections to the slide. The slides containing sections were air dried and kept in cool place until staining. The sectioned tissues were deparaffinized in three changes of xyline. Then the tissues were rehydrated through descending grades of alcohol. The sections were stained with Harris hematoxylin and eosin. Finally the sections were mounted with cover slip using DPX and dried (Luna, 1968). The tissues were examined under microscope and photomicrograph was taken using compound microscope and photomicrographic camera (Olympus PM-C 35 Model).

\section{RESULTS AND DISCUSSION}

A total of 80 buffaloes respiratory tract (trachea and lung) were examined and of them 09 trachea (out of 80) and 30 lungs (out of 80) were found to be apparently abnormal in naked eye. The occurrence of tracheal petechial haemorrhages was recorded $11.25 \%$ (Table 1) and histopathologically, the occurrence of different tracheal lesions diagnosed under microscope is shown in Table 2. Overall tracheal lesions were 13.75\% of which congestion was $5 \%$ and mild tracheitis was $8.75 \%$. The similar tracheal haemorrhage was described by Radostits et al. (2002) and Jubb et al. (1997) but some other lesions like tracheal edema, obstruction of trachea, pustular lesion were also described by Radostits et al. (2002).

Table 1. Gross lesions of trachea and lungs of buffaloes

\begin{tabular}{|l|l|l|l|}
\hline \multirow{2}{*}{ Organs } & Findings & \multicolumn{2}{l|}{ Disorders/conditions (n = 80) } \\
\cline { 3 - 4 } & & No. & $\%$ \\
\hline Trachea & Petechial hemorrhages in trachea & 09 & 11.25 \\
\hline \multirow{4}{*}{ Lungs } & Haemorrhages and congestion in lungs & 13 & 16.25 \\
\cline { 2 - 4 } & Hard nodule formation & 6 & 7.5 \\
\cline { 2 - 4 } & Presence of cyst in lungs & 5 & 6.25 \\
\cline { 2 - 4 } & Emphysematous lungs & 4 & 5 \\
\cline { 2 - 4 } & Thickened pleura & 2 & 2.5 \\
\cline { 2 - 4 } & Total & 30 & 37.5 \\
\hline
\end{tabular}

$\mathrm{n}=$ Total number of samples examined.

The gross lesions of lungs were $37.5 \%$ in buffaloes (Table 1). Grossly, five types of lung lesions were recorded such as haemorrhages and congestion in lungs (16.25\%), hard nodule formation (7.5\%), cyst in lungs (6.25\%), emphysematous lungs (5\%) and thickened pleura (2.5\%) (Table 1). The overall gross lesions of lungs recorded were $37.5 \%$. The similar lesions were also described by many authors (Hussain, 1992; Jones et al., 1997; Jubb et al., 1997; Radostits et al., 2002). Some other gross lesions like black coloured lungs, pus in lungs were recorded by Jubb et al. (1997) and Radostits et al. (2002), but no such lesions were recorded in the present investigation.

Histopathologically, different types of pneumonic lesions and some other lesions were found in the lungs (Table 2). Chronic interstitial pneumonia was 3.75\% which was characterized by the thickened alveolar septae due to accumulation of inflammatory cells and proliferation of fibrous connective tissue. Inflammatory cells were macrophages containing hemosiderin pigments and lymphocytes. Exudates and hemorrhage was present within the alveoli (Fig. 1). Edema fluid was found in 3.75\% cases and it was characterized by presence of pink color edematous fluid in between lung alveoli and inflammatory cells mainly neutrophils. Broncho-pneumonia was $3.75 \%$ and its features were the presence of exudates and infiltration of inflammatory cells in the bronchiolar wall as well as in the lumen of bronchiole. There was also presence of exudates within the alveoli and showed slight necrosis of the alveoli (Fig. 2). 
Pathology of trachea and lungs of buffaloes

Table 2. Histopathological lesions of trachea and lungs of buffaloes

\begin{tabular}{|l|l|l|l|}
\hline \multirow{3}{*}{ Organs } & Findings & \multicolumn{2}{l}{ Disorders/conditions (n = 80) } \\
\cline { 3 - 4 } & & No. & $\%$ \\
\hline \multirow{5}{*}{ Trachea } & Congestion & 04 & 5 \\
\cline { 2 - 4 } & Mild tracheitis & 07 & 8.75 \\
\cline { 2 - 4 } & Total & $\mathbf{1 1}$ & $\mathbf{1 3 . 7 5}$ \\
\hline & Chronic interstitial pneumonia & 03 & 3.75 \\
\cline { 2 - 4 } & Edema fluid & 03 & 3.75 \\
\cline { 2 - 4 } & Broncho pneumonia & 03 & 3.75 \\
\cline { 2 - 4 } & Bronchitis & 02 & 2.5 \\
\cline { 2 - 4 } & Bronchiolitis & 02 & 2.5 \\
\cline { 2 - 4 } & Pneumonia congested stage & 07 & 8.75 \\
\cline { 2 - 4 } & Hydatid cyst & 05 & 6.25 \\
\cline { 2 - 4 } & Fibrinous pneumonia & 03 & 3.75 \\
\cline { 2 - 4 } & Healed nodule & 06 & 7.5 \\
\cline { 2 - 4 } & Purulent bronchopneumonia & 01 & 1.25 \\
\cline { 2 - 4 } & Fibrino-purulent pneumonia & 01 & 1.25 \\
\cline { 2 - 4 } & Subacute fibrinous pneumonia & 01 & 1.25 \\
\cline { 2 - 4 } & Pulmonary adenomatosis & 01 & 1.25 \\
\cline { 2 - 4 } & Pleuritis & 02 & 2.5 \\
\cline { 2 - 4 } & Hemosiderosis & 03 & $\mathbf{5 3}$ \\
\cline { 2 - 4 } & Total & $\mathbf{4 3}$ & \\
\hline
\end{tabular}

$\mathrm{n}=$ Total number of samples examined.

Bronchitis was $2.5 \%$ in cases and it was characterized by the presence of exudates in most of the lumen of the bronchus. Infiltration of inflammatory cells was found in and around the bronchial wall. There was presence of haemorrhage in some alveoli and congestion of blood vessels. Bronchiolitis which was characterized by the infiltration of reactive cells in and around the bronchiolar wall and necrotic lesions in mucosal epithelia was recorded in $2.5 \%$ cases. In other areas of lung tissue, there was presence of haemorrhage in the alveoli and congestion of blood vessels. Congested stage of pneumonia was $8.75 \%$ and it was characterized by the presence of excessive hemorrhage within the alveoli and inters alveolar septa associated with leukocytic infiltration. Haemorrhage and leukocytic infiltration were also found in the lumen of the bronchus. The wall of the bronchus also showed the inflammatory changes and mild necrosis in the mucosal layer. In some places, only pink colour edema fluid was present in the lumen of the alveoli. Hydatid cyst was noticed in $6.25 \%$ cases while fibrinous pneumonia, healed nodule, purulent broncho-pneumonia, fibrino-purulent pneumonia, subacute fibrinous pneumonia, pulmonary adenomatosis, pleuritis and hemosiderosis were also recorded here in 3.75\%, 7.5\%, $1.25 \%, 1.25 \%, 1.25 \%, 1.25 \%, 2.5 \%$ and $3.75 \%$ cases, respectively. Hydatid cyst was characterized by the cyst wall was composed of proliferation of fibrous connective tissue with infiltration of mononuclear cells and few eosinophils (Fig. 3). In fibrinous pneumonia, there were presences of collagen fiber associated with few reactive cells. In addition, reactive cells were also found in the lumen of bronchiole and some in alveoli and interalveolar septa. There was diffuse alveolar necrosis and edema in the inter-alveolar septa and sloughing of bronchial mucosa. Healed nodule was characterized by the nodular areas showed excessive proliferation of fibrous connective tissue indicating the feature of healing. In addition, multifocal nodules, characterized by the presence of lymphocytes, macrophages and giant cells were found (Fig. 4). Purulent broncho-pneumonia was characterized by the presence of inflammatory cells consisted of mainly neutrophils within the lumen of bronchiole. Adjacent to the bronchioles, there were focal infiltration of large number of neutrophils and few lymphocytes. On the other part of the lung tissue, there were the presence of plasma cells, macrophages and lymphocytes (Fig. 5). Presences of neutrophil, collagen fiber, macrophage, edema fluid and hemosiderin pigment were found in fibrino-purulent pneumonia. Subacute fibrinous pneumonia was characterized by the presence of immature collagen fiber associated with few reactive cells. The glandular pattern of growth due to pneumocyte type-II cells proliferation was noticed in pulmonary adenomatosis. 


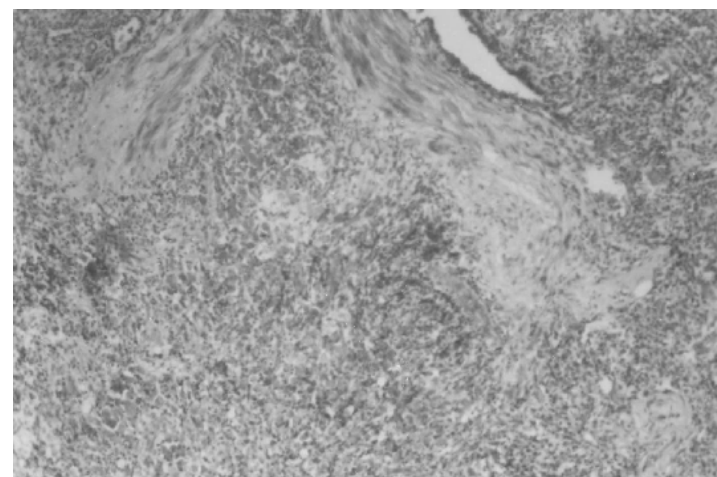

Fig. 1. Section of lung showing chronic interstitial pneumonia: Note the inflammatory cells are macrophages containing hemosiderin pigment and lymphocyte (H \& E, × 83).

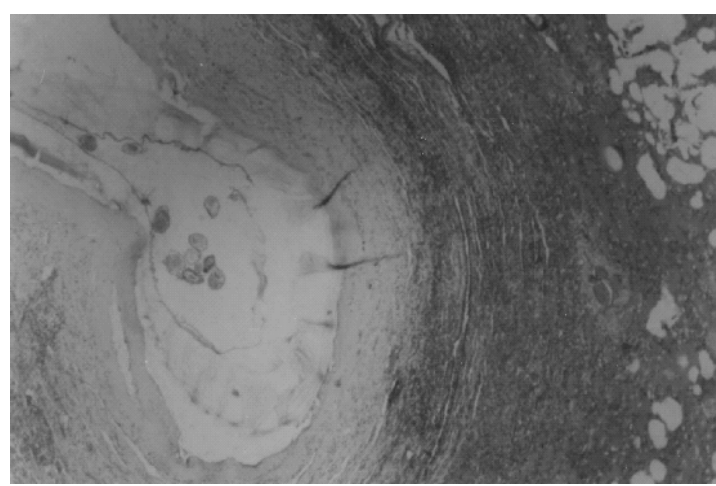

Fig. 3. Section of the cyst wall in lung showing infiltration of inflammatory cells and proliferation of fibrous connective tissue around the cystic wall ( $\mathrm{H} \& \mathrm{E}$, $\times 330$ ).

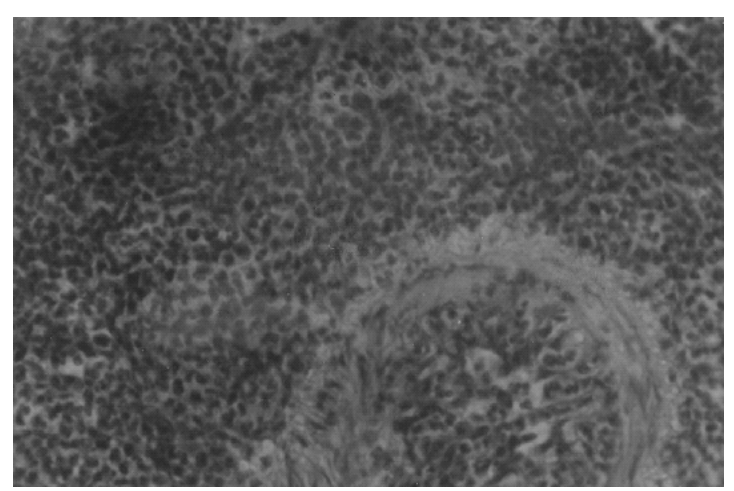

Fig. 5. Section of lung showing purulent bronchopneumonia: characterized by the presence of inflammatory cells mainly neutrophils within the lumen of bronchiole. Adjacent to the bronchioles, presence of neutrophils and lymphocytes. (H \& E, × 330).

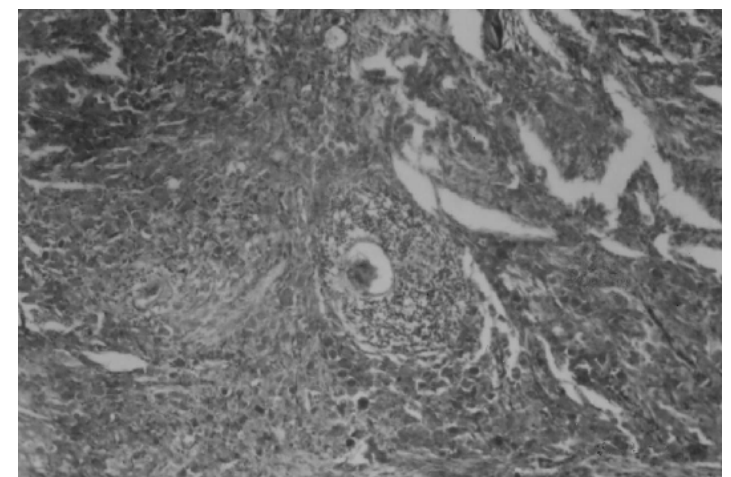

Fig. 2. Sections of lung showing broncho-pneumonia: Note the inflammatory cells present in and around the bronchial wall and exudates present within the alveoli (H \& E, × 330).

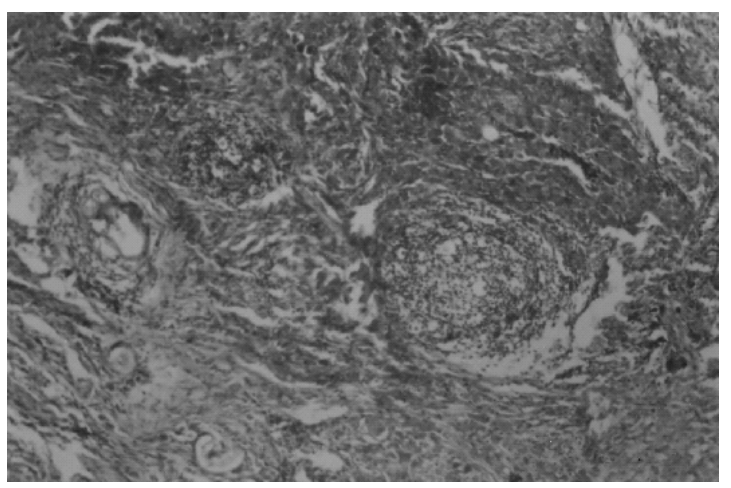

Fig. 4. Section of lung showing healed nodule: Note the excessive proliferation of fibrous connective tissue with the presence of multifocal nodules characterized by the presence of lymphocytes, macrophages and giant cells ( $\mathrm{H}$ $\& \mathrm{E}, \times 83)$.

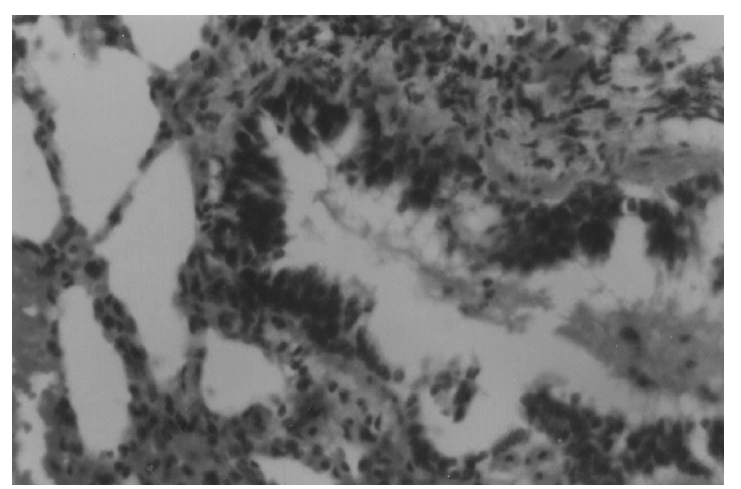

Fig. 6. Section of lung showing hemosiderosis: characterized by the presence of yellow coloured hemosiderin pigments in the macrophages and RE cells (H \& E, $\times$ 83). 
The presence of edema fluid and inflammatory cells indicated pleuritis while hemosiderosis was characterized by the presence of yellow coloured hemosiderin pigment in the macrophages and RE cells (Fig.6). For morphological descriptions, the lesions were categorized into various types; however a single section showed intermixed of various lesions. The overall histopathological lesions of lungs were recorded 53.75\%. Like the present investigation, similar lesions have been described by other authors (Haridy et al., 2006; Manandhar et al., 2006; Jones et al., 1997; Jubb et al., 1997; Radostits et al., 2002; Gogolewski et al., 1987; Gupta et al., 1978; Verma and Kalra, 1974; Rathore and Singh, 1970; Dwivedi, 1968).

Though, the causative agents were not identified from the lesions, the findings of this investigation will help the veterinarian to know the nature and type of common pathological lesions of respiratory system of buffaloes.

\section{ACKNOWLEDGEMENTS}

The authors would like to express gratefulness and thank to The Ministry of Science and Information \& Communication Technology of The People’s Republic of Bangladesh for providing fund of this project work.

\section{REFERENCES}

1. Banerjee GC (1998). A Text Book of Animal Husbandry. $8^{\text {th }}$ edn., Oxford and IBH Publishing Co. Pvt. Ltd., New Delhi.

2. BBS (2003). National Accounts Statistics May 2003. Bangladesh Bureau of Statistics, Ministry of Planning, Government of the People's Republic of Bangladesh.

3. Dewan ML, Hossain MI and Baki MA (1979). Pathological investigation on the mortality of the buffalo calves of Bangladesh. The Bangladesh Veterinarian 13: 1-7.

4. Dwivedi JN (1968). Histopathological study on some forms of pneumonia in adult buffaloes. Indian Journal of Animal Sciences 7: 213-217.

5. Gogolewski RP, Leathers CW, Liggitt HD and Corbeil LB (1987). Experimental Haemophilus somnus pneumonia in calves and immunoperoxidase localization of bacteria. Veterinary Pathology 24 (3): 250-256.

6. Gupta PP, Singh B, Mandal PC, Gill BS and Grewal GS (1978). A postmortem study of mortality pattern in adult buffaloes in Punjab, India. Indian Journal of Animal Sciences 48: 669- 673.

7. Haridy FM, Ibrahim BB, Elshazly AM, Awad SE, Sultan DM, El-Sherbini GT and Morsy TA (2006). Hydatidosis, Echinococcus granulosus in Egyptian slaughtered animals in the years 2000-2005. Journal of Egyptian Society of Parasitology 36 (3): 1087-1100.

8. Hossain MI (1990). A survey on the diseases of domesticated water buffaloes at Kanihari (Senbari) Union of Mymensingh district. Bangladesh Agricultural University Research Progress 5: 344 - 348.

9. Hossain MI and Baki MA (1987). Pathological studies on intestinal amphistomiasis in buffaloes. The Bangladesh Veterinarian 4: 29-30.

10. Hossain MI, Rabbani SMB and Huque AKMF (1991). Pathological investigation on buffalo diseases in Bangladesh. I. Gastro-intestinal nematodiasis and its treatment with herbal anthelmintics. The Bangladesh Veterinarian 8: 18-21.

11. Hussain A, Maqbool A, Hussain S, Athar M, Shakoor A and Amin MK (1992). Studies on prevalence and organ specificity of hydatidosis in ruminants slaughtered at karachi and Faisalabad abattoir. Pakistan Journal of Dairy Science 54 (9): 454-456.

12. Jones TC, Hunt RD and King NW (1997). Veterinary Pathology. $6^{\text {th }}$ edn., Williams and Wilkins, USA. p. 345.

13. Jubb KVF, Kennedy PC and Palmer N (1997). Pathology of Domestic Animals. $4^{\text {th }}$ edn., Vol. 2, Academic Press, Inc. USA. p. 638.

14. Luna LG (1968). Manual of Histologic Staining Methods of the Armed Forces Institute of Pathology. $3^{\text {rd }}$ edn., McGraw Hill Book Co. New York.

15. Manandhar S, Horchner F, Morakote N, Kyule MN and Baumann MP (2006). Occurrence of hydatidosis in slaughter buffaloes (Bos bubalis) and helminths in stray dogs in Kathmandu Valley, Nepal. Berlin Munch Tierarztl. Wochenschr 119 (7-8): 308-311.

16. Radostits OM, Blood DC and Gay CC (2002). Veterinary Medicine. A Text Book of the Diseases of Cattle, Sheep, Pigs, Goats and Horses. $13^{\text {th }}$ edn., Billiere Tindall. USA. pp. 545-591.

17. Rathore BS and Singh NP (1970). Pneumonia in buffaloes- A pathological study. Indian Journal of Animal Sciences 40: 499-507.

18. Verma PC and Kalra DS (1974). Mortality in buffalo calves (Bos bubalis). Indian Journal of Animal Sciences 44: 163168. 